\title{
A Method for Prolonging Culturing Time of Banana Seedling in Nursery Shed
}

\author{
Shenghe Chang1,2\#, Zhengjing Wu ${ }^{3 \#}$, Qi Zeng3\#, Jingyi Zhang3\#, Wei Sun ${ }^{1,2}$, Lan Qiao3 ${ }^{3}$, Haiyan Shu ${ }^{1,2^{*}}$ \\ ${ }^{1}$ Haikou Experimental Station, Chinese Academy of Tropical Agricultural Sciences, Haikou, China \\ ${ }^{2}$ The Key Lab of Hainan Banana Genetics and Breeding, Haikou, China \\ ${ }^{3}$ School of Forestry, Henan University of Science and Technology, Luoyang, China \\ Email: *shuhycatas@163.com
}

How to cite this paper: Chang, S.H., Wu, Z.J., Zeng, Q., Zhang, J.Y., Sun, W., Qiao, L. and Shu, H.Y. (2019) A Method for Prolonging Culturing Time of Banana Seedling in Nursery Shed. Advances in Bioscience and Biotechnology, 10, 119-131. https://doi.org/10.4236/abb.2019.105009

Received: April 15, 2019

Accepted: May 20, 2019

Published: May 23, 2019

Copyright $\odot 2019$ by author(s) and Scientific Research Publishing Inc. This work is licensed under the Creative Commons Attribution-NonCommercial International License (CC BY-NC 4.0). http://creativecommons.org/licenses/by-nc/4.0/ (c) (7) (8) Open Access

\begin{abstract}
Banana industry plays important roles in the economics of southern China, where is always blown by typhoon in summer and autumn. After typhoon passed through, fresh banana seedlings are often required. That is a problem for companies on culturing banana seedling, since culturing banana seedlings takes about four months and typhoon cannot be predicted so early. If the growth of banana seedlings can be slowed down and the seedlings can be cultured in nursery shed for more time, this problem will be solved. In this research, seven treatments (paclobutrazol, diniconazole, paclobutrazol + brassins, paclobutrazol + diethyl aminoethyl hexanoate, diniconazole + brassins, diniconazole + diethyl aminoethyl hexanoate, chlormequat chloride) were performed on banana seedlings and the growth was measured. Results showed that in all of the treatments, the values of plant height, leaf length, pseudostem diameters, root length, root weight, root volume, fresh weight of above-ground tissues and fresh weight of seedlings were significantly less than those corresponding values of control. The reducing powers of roots of seedlings sprayed with paclobutrazol and paclobutrazol + diethyl aminoethyl hexanoate were remarkably higher than those of seedlings treated with water. Total chlorophyll content in leaves of seedlings sprayed with paclobutrazol was remarkably higher than that of seedlings treated with water. Total chlorophyll contents in leaves of seedlings treated with paclobutrazol + diethyl aminoethyl hexanoate and chlormequat chloride were lower than those of control. For delaying the growth of banana seedlings, chlormequat chloride was the best among the seven treatments. The mechanism might be that the enzyme CPP-synthase in seedlings was inhibited by chlormequat chloride.
\end{abstract}

\section{Keywords}

Banana, Tissue-Culturing Seedling, Plant Retardant, Gibberellin

${ }^{\#}$ Equal contributor. ${ }^{\star}$ Corresponding author. 


\section{Introduction}

China is a main-banana producer in the world. Guangdong, Guangxi, Hainan, Fujian, Yunnan and Taiwan are the main banana-producing provinces in China [1]. These provinces are always blown heavily by typhoon in summer and autumn [1] [2]. After typhoon passed through, fresh banana seedlings were always wanted for replanting. Culturing healthy-banana seedlings takes about four months. Seedling companies need to decide how many seedlings required in the last year. If too many seedlings were cultured, there is a high possibility that some seedlings cannot be sold. Furthermore, seedlings cannot be stocked in nursery shed for a long time, since the nutrition in the culturing bowl was limited. In fact, banana seedlings can be grown in nursery shed for three months at the most. At the same time, typhoon cannot be predicted so early. There are high possibilities that no fresh seedlings can be bought from the companies after typhoon. How to guarantee that there are fresh seedlings for selling, at the same time, seedlings would be sold and not be discarded, is a problem for banana-seedling companies.

Growth retardants can delay the growth of plants [3]-[8]. If the growth of some banana seedlings in nursery shed was slowed down, they might be sold after typhoon for replanting. In this research, several growth retardants were screened for delaying the growth of banana seedlings. Results showed that the best retardant, chlormequat chloride, can prolong the culturing time of banana seedlings in nursery shed for two months. The mechanisms of the growth retardants were also discussed.

\section{Materials and Methods}

\subsection{Materials}

Tissue-culture seedlings of Banana (Musa acuminate AAA Cavendish cv. Brazil) were cultivated in the Center of Seedlings, Chinese Academy of Tropical Agricultural Sciences, Danzhou, China. When the third leaf appeared, seedlings in culturing bottles were transferred to plastic pots containing gardening soil. The seedlings were sprayed with water containing macronutrients $(10 \mathrm{mg} / \mathrm{L})$ of $\mathrm{Mu}$ rashige \& Skoog medium one time every two days. One month later, the seedlings were treated with growth retardants. All of the chemicals used in this research were bought from Sigma (USA).

\subsection{The Seedlings Were Treated with Growth Retardants}

Seven treatments were performed in this research. The treatments were paclobutrazol $(200 \mathrm{mg} / \mathrm{L})$, diniconazole $(200 \mathrm{mg} / \mathrm{L})$, paclobutrazol + brassins $(200 \mathrm{mg} / \mathrm{L}+$ $0.05 \mathrm{mg} / \mathrm{L})$, paclobutrazol + diethyl aminoethyl hexanoate $(200 \mathrm{mg} / \mathrm{L}+10 \mathrm{mg} / \mathrm{L})$, diniconazole + brassins $(200 \mathrm{mg} / \mathrm{L}+0.1 \mathrm{mg} / \mathrm{L})$, diniconazole + diethyl aminoethyl hexanoate $(200 \mathrm{mg} / \mathrm{L}+20 \mathrm{mg} / \mathrm{L})$, chlormequat chloride $(200 \mathrm{mg} / \mathrm{L})$ respectively. One hundred milliliter of solution was sprayed onto the above-ground tissues of seedling every time. Four replicates were done for every treatment. Distilled wa- 
ter was sprayed as control. The treatments were performed every 7 days. The seedlings were sprayed for three times. After 30 days, the materials were collected for measurement.

\subsection{Determination for Chlorophyll Content in Leaves}

Two-hundred milligrams of fresh leaves were ground with $2.5 \mathrm{ml}$ of $95 \%$ ethanol in a mortar. Ten milliliters of $95 \%$ ethanol was added into the serum and continued grounding until the color of the serum showed white. The mixture was stood still for 5 minutes. The serum was filtered using analytical-filter paper. The filtrate was stocked in a brown bottle. The chlorophyll on the mortar and filter paper were washed with ethanol and the solution was also collected in the bottle. Ethanol was added until the volume of the solution was $25 \mathrm{ml}$. The absorbance of the solution was determined using a spectrophotometer at $665 \mathrm{~nm}$ and 649 $\mathrm{nm}$, respectively. The chlorophyll content was calculated according to the following formula.

$$
\begin{aligned}
& \text { Chla }=(13.95 \mathrm{~A} 665-6.88 \mathrm{~A} 649) \times \mathrm{V} / 1000 \mathrm{~W} . \\
& \text { Chlb }=(24.96 \mathrm{~A} 649-7.32 \mathrm{~A} 665) \times \mathrm{V} / 1000 \mathrm{~W} .
\end{aligned}
$$

\subsection{Measurement for Reducing Power of the Seedling Root}

Two-hundred milligrams of root tips were collected and put into a 10-ml beaker. Five milliliters of $0.4 \%$ TTC and $5 \mathrm{ml}$ of phosphate buffer were added. The roots were soaked into the solution completely. After being kept in darkness for 2 hours at $37^{\circ} \mathrm{C}, 2 \mathrm{ml}$ of $1 \mathrm{~mol} / \mathrm{L} \mathrm{H}_{2} \mathrm{SO}_{4}$ was added. The roots were taken out and the water on the roots was soaked up with absorbent paper. The roots were ground with $3.5 \mathrm{ml}$ of ethyl acetate in a mortar. The serum was transferred into a test tube. The debris was washed with ethyl acetate for three times. The solutions were all transferred into the test tube. Ethyl acetate was added until the solution volume was $10 \mathrm{ml}$. the absorbance of the solution was measured using a spectrophotometer at the wavelength of $485 \mathrm{~nm}$. Compared with the standard curve, the reducing quantity of tetrazole was calculated.

\section{Results}

\subsection{Seedling Height Was Inhibited Significantly after Banana Seedling Was Sprayed with Growth Retardants}

After banana seedlings were treated with chemicals for 30 days, the heights of the treated seedlings were significantly lower than those of seedlings sprayed with water. For example, after being sprayed with chlormequat chloride for 30 days, the height of the treated was $14.2 \pm 0.7 \mathrm{~cm}$, while the height of seedlings sprayed with water was $23.6 \pm 1.0 \mathrm{~cm}$ (Figure 1). The height of the seedlings treated with other growth retardants were also significantly lower than that of control (Figure 1). Among the seedlings treated, the height of seedlings sprayed with chlormequat chloride was the lowest. This indicated that for inhibiting the height of banana seedling, spraying chlormequat chloride was the best choice. 


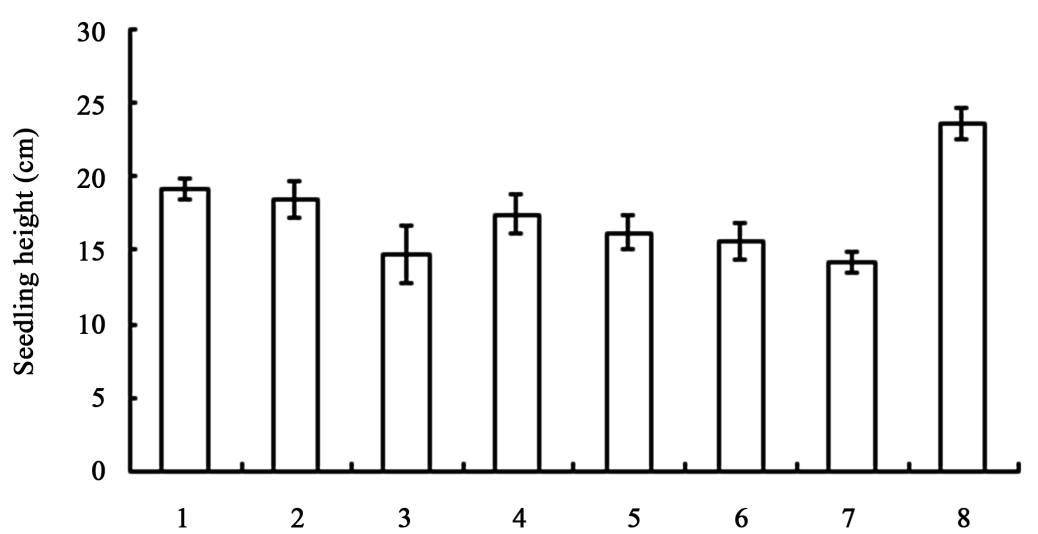

Figure 1. The heights of seedlings treated with different growth retardants. 1 - 8 represented paclobutrazol, diniconazole, paclobutrazol + brassins, paclobutrazol + diethyl aminoethyl hexanoate, diniconazole + brassins, diniconazole + diethyl aminoethyl hexanoate, chlormequat chloride, water, respectively.

\subsection{Leaf Growth of Banana Seedlings Can Be Suppressed Remarkable by Growth Retardants}

Leaves of all seedlings sprayed with retardants were shorter than those of seedlings sprayed with water (Figure 2). Among the treatments, the leaves of the seedlings treated with chlormequat chloride were the shortest (Figure 2). For leaf width, the differences among seedlings treated with paclobutrazol, diniconazole and the control were not significant (Figure 3). The leaf width of seedlings treated with paclobutrazol + brassins, paclobutrazol + diethyl aminoethyl hexanoate, diniconazole + brassins, diniconazole + diethyl aminoethyl hexanoate and chlormequat chloride were remarkably less than those of control (Figure 3). Generally, for inhibiting leaf growth of banana seedlings, spraying paclobutrazol + brassins and chlormequat chloride were better than other treatments.

\subsection{Pseudostem Diameters of Banana Seedlings Sprayed with Growth Retardants Were Less than Those of Control}

All of the pseudostem diameters of seedlings sprayed with growth retardants were less than those of seedlings sprayed with water. However, except that the pseudostem diameter of seedlings treated with diniconazole + brassins was bigger than that of seedlings sprayed with diniconazole + diethyl aminoethyl hexanoate, the differences among the pseudostem diameters of seedlings treated with other growth retardants were not significant. Comparatively, for inhibiting the growth of pseudostem diameter, the effect of diniconazole + diethyl aminoethyl hexanoate was better than other treatments used in this research (Figure 4).

\subsection{Fresh Weights of All Seedlings Can Be Inhibited Significantly by Growth Retardants}

After banana seedlings were sprayed with growth retardants, fresh weights of all seedlings treated with growth retardants were significantly lower than those of control. On the $30^{\text {th }}$ day, the fresh weight of seedlings treated with paclobutrazol 


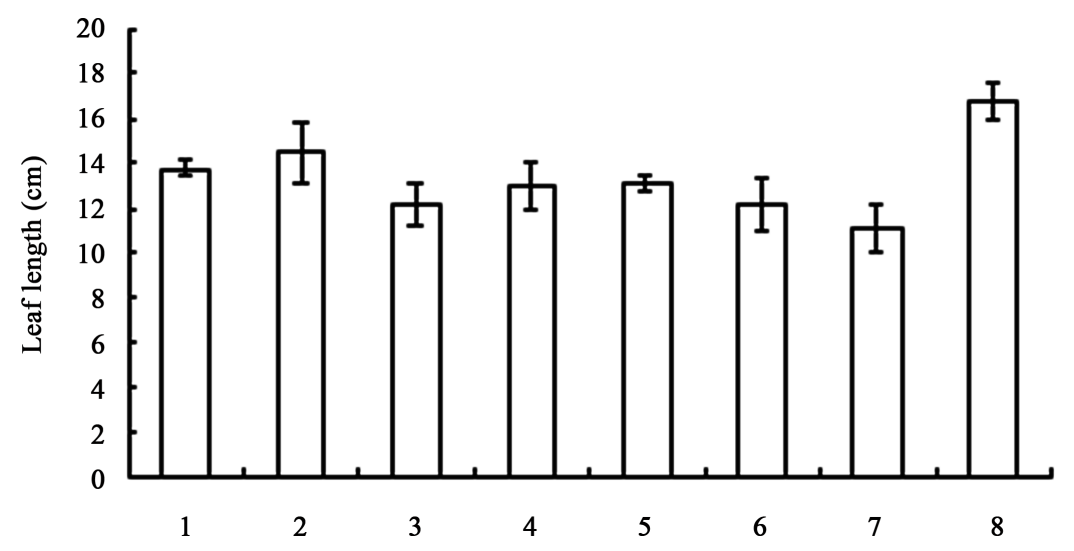

Figure 2. Leaf length of banana seedlings sprayed with different growth retardants. 1 - 8 represented paclobutrazol, diniconazole, paclobutrazol + brassins, paclobutrazol + diethyl aminoethyl hexanoate, diniconazole + brassins, diniconazole + diethyl aminoethyl hexanoate, chlormequat chloride, water, respectively.

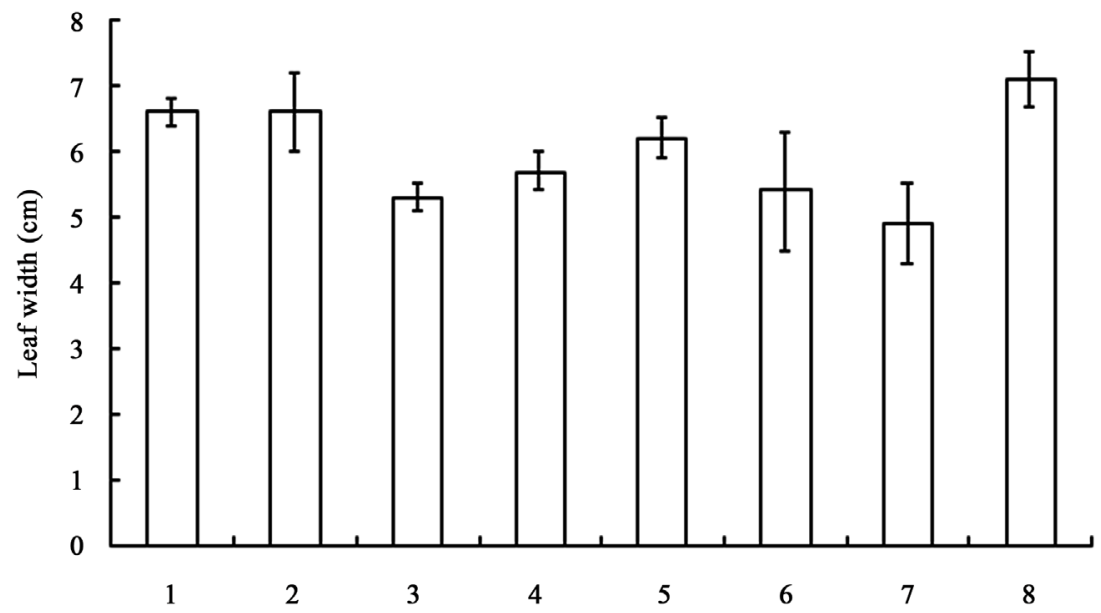

Figure 3. Leaf width of banana seedlings treated with growth retardants. 1 - 8 represented paclobutrazol, diniconazole, paclobutrazol + brassins, paclobutrazol + diethyl aminoethyl hexanoate, diniconazole + brassins, diniconazole + diethyl aminoethyl hexanoate, chlormequat chloride, water, respectively.

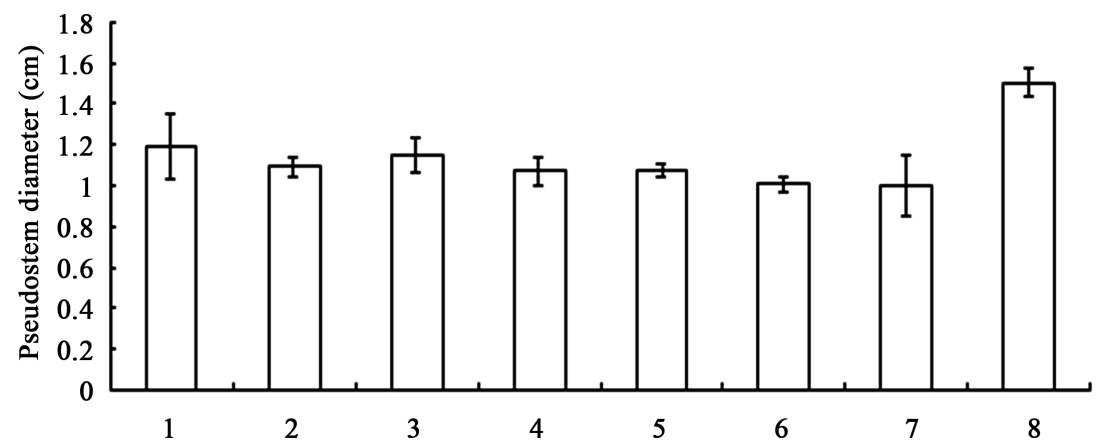

Figure 4. Pseudostem diameters of seedlings treated with growth retardants. 1 - 8 represented paclobutrazol, diniconazole, paclobutrazol + brassins, paclobutrazol + diethyl aminoethyl hexanoate, diniconazole + brassins, diniconazole + diethyl aminoethyl hexanoate, chlormequat chloride, water, respectively. 
+ brassins was $13.01 \pm 0.5 \mathrm{~g}$, while the corresponding value of seedlings sprayed with water was $23.66 \pm 1.5 \mathrm{~g}$. Among the treatments, the fresh weight of seedlings treated with paclobutrazol + brassins was significantly less than those of seedlings treated with paclobutrazol, diniconazole and paclobutrazol + diethyl aminoethyl hexanoate. But the differences among the fresh weights of seedlings sprayed with paclobutrazol + brassins, paclobutrazol + diethyl aminoethyl hexanoate, diniconazole + brassins, diniconazole + diethyl aminoethyl hexanoate and chlormequat chloride were not significant. For inhibiting the fresh weight of banana seedlings, the effects of paclobutrazol, diniconazole and paclobutrazol + diethyl aminoethyl hexanoate were less than that of paclobutrazol + brassins (Figure 5).

\subsection{The Growth of Above-Ground Tissues Was Inhibited Significantly by the Retardants}

After seedlings were sprayed with growth retardants, all of the fresh weights of the above-ground tissues (FWAT) were significantly lower than that of control (Figure 6). Among the treatments, the FWATs of seedlings sprayed with

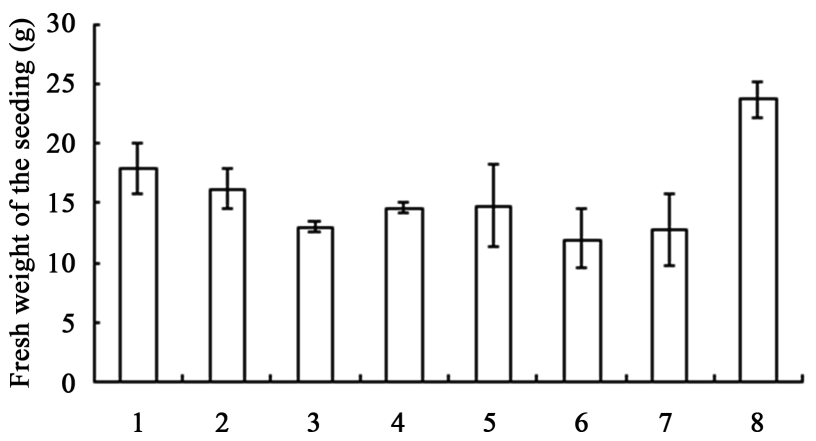

Figure 5. Fresh weights of seedlings sprayed with different growth retardants. $1-8$ represented paclobutrazol, diniconazole, paclobutrazol + brassins, paclobutrazol + diethyl aminoethyl hexanoate, diniconazole + brassins, diniconazole + diethyl aminoethyl hexanoate, chlormequat chloride, water, respectively.

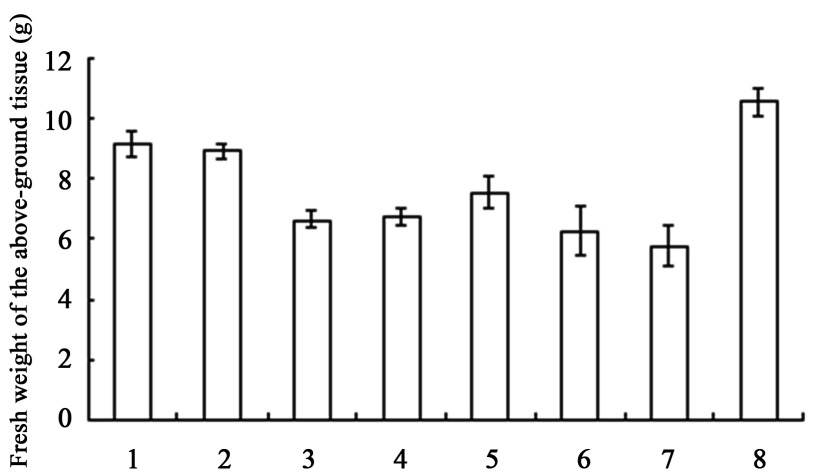

Figure 6. Fresh weights of the above-ground tissues of banana seedlings treated with different growth retardants. 1 - 8 represented paclobutrazol, diniconazole, paclobutrazol + brassins, paclobutrazol + diethyl aminoethyl hexanoate, diniconazole + brassins, diniconazole + diethyl aminoethyl hexanoate, chlormequat chloride, water, respectively. 
paclobutrazol + brassins, paclobutrazol + diethyl aminoethyl hexanoate and chlormequat chloride were less than those of seedlings treated with paclobutrazol or diniconazole (Figure 6). Although the FWAT of seedlings sprayed with chlormequat chloride was lower than those of seedlings treated with paclobutrazol + brassins or paclobutrazol + diethyl aminoethyl hexanoate, the differences between the FWATs of seedlings sprayed with of diniconazole + diethyl aminoethyl hexanoate and chlormequat chloride were not significant (Figure 6). Comparatively, chlormequat chloride has the best effect in inhibiting the growth of above-ground tissues of banana seedlings among the seven treatments.

\subsection{The Growth of Roots Was Inhibited Significantly after Seedlings Were Sprayed with Retardants}

After banana seedlings were treated with growth retardants for 30 days, the fresh weights of roots (FWT) of banana seedlings treated with growth retardants were remarkably lower than that of the control (Figure 7). However, the differences among the FWTs of banana seedlings sprayed with different retardants were not significant (Figure 7). Similar results can also be found in root length and root volume (Figure 8 and Figure 9). These demonstrated that the growth of root was sensitive to growth retardants. Growth retardants can inhibit the growth of root significantly. For inhibiting the growth of roots, these retardants had similar effects.

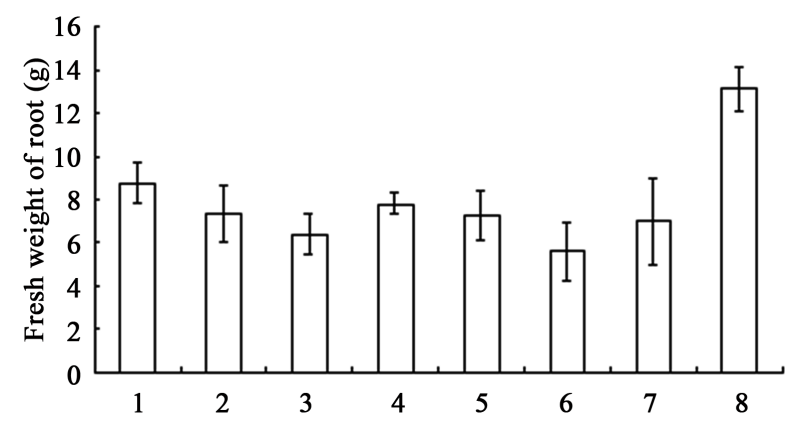

Figure 7. Fresh weights of roots of banana seedlings sprayed with growth retardants. 1 - 8 represented paclobutrazol, diniconazole, paclobutrazol + brassins, paclobutrazol + diethyl aminoethyl hexanoate, diniconazole + brassins, diniconazole + diethyl aminoethyl hexanoate, chlormequat chloride, water, respectively.

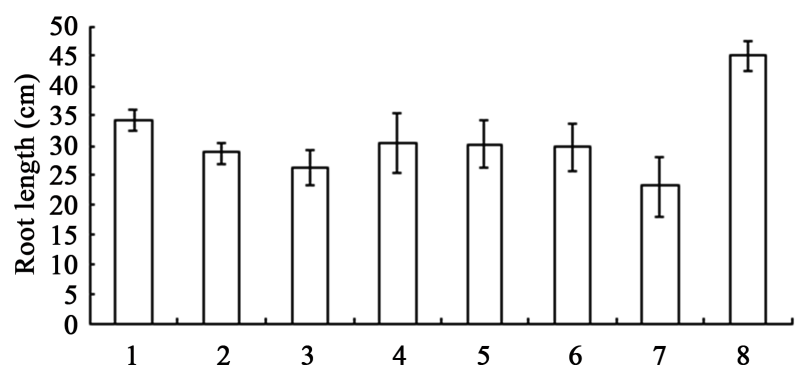

Figure 8. Root length of banana seedlings sprayed with different growth retardants. 1 - 8 represented paclobutrazol, diniconazole, paclobutrazol + brassins, paclobutrazol + diethyl aminoethyl hexanoate, diniconazole + brassins, diniconazole + diethyl aminoethyl hexanoate, chlormequat chloride, water, respectively. 


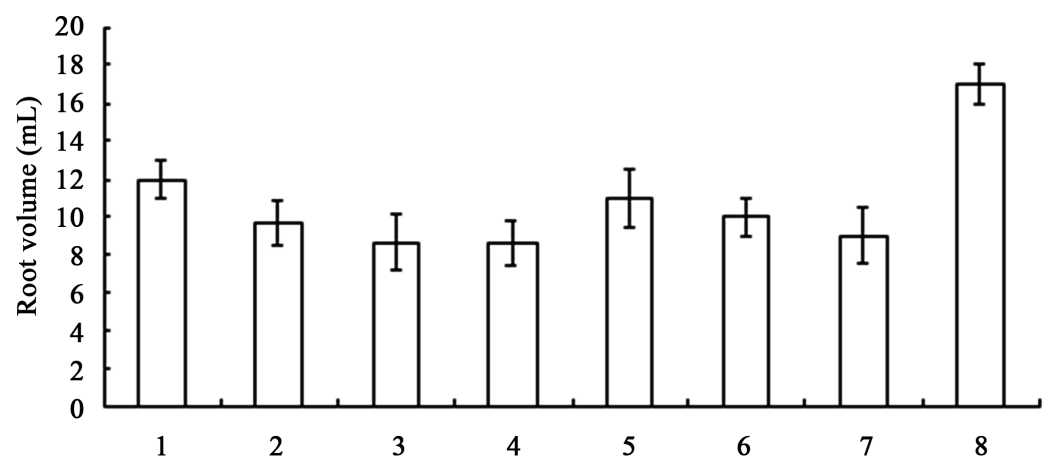

Figure 9. Root volume of banana seedlings sprayed with growth retardants. 1 - 8 represented paclobutrazol, diniconazole, paclobutrazol + brassins, paclobutrazol + diethyl aminoethyl hexanoate, diniconazole + brassins, diniconazole + diethyl aminoethyl hexanoate, chlormequat chloride, water, respectively.

\subsection{Reducing Power of Roots of Seedlings Sprayed with Paclobutrazol or Paclobutrazol + Diethyl Aminoethyl Hexanoate Was Higher than That of Seedlings Treated with Water}

After the seedlings were sprayed with retardants, reducing powers of root (RPT) of banana seedlings sprayed with paclobutrazol or paclobutrazol + diethyl aminoethyl hexanoate was significantly higher than that of seedlings treated with water. However, the differences among RPTs of seedlings sprayed with diniconazole, paclobutrazol + brassins, diniconazole + brassins, diniconazole + diethyl aminoethyl hexanoate, chlormequat chloride and the control were not significant. The differences among RPTs of seedlings treated with paclobutrazol, diniconazole, paclobutrazol + brassins and paclobutrazol + diethyl aminoethyl hexanoate were not significant either. These demonstrated that except paclobutrazol and paclobutrazol + diethyl aminoethyl hexanoate, other growth retardants had no obvious role in improving RPTs of banana seedlings (Figure 10).

\subsection{Chlorophyll Content in Leaves of Banana Seedlings Sprayed with Paclobutrazol + Diethyl Aminoethyl Hexanoate or Chlormequat Chloride Was Less than That of Seedlings Treated with Water}

Results showed that chlorophyll A contents in leaves of seedlings treated with paclobutrazol + diethyl aminoethyl hexanoate or chlormequat chloride was significantly lower than that of seedlings sprayed with water (Figure 11). Chlorophyll A contents of seedlings treated with paclobutrazol or paclobutrazol + brassins was significantly higher than that of control (Figure 11). But the differences among the corresponding values of seedlings treated with diniconazole, diniconazole + brassins, diniconazole + diethyl aminoethyl hexanoate and the control were not significant (Figure 11). Chlorophyll B contents in leaves of seedlings treated with diniconazole, paclobutrazol + diethyl aminoethyl hexanoate, diniconazole + brassins, diniconazole + diethyl aminoethyl hexanoate, chlormequat chloride were lower than that of control (Figure 12). Total chlorophyll content 
in leaves of seedlings sprayed with paclobutrazol was higher than that of seedlings treated with water (Figure 13). Total chlorophyll contents in leaves of seedlings treated with paclobutrazol + diethyl aminoethyl hexanoate or chlormequat chloride was lower than of control (Figure 13). The differences between the corresponding values of control and other treatments were not significant (Figure 13). These demonstrated that retardant paclobutrazol can improve chlorophyll A content and total chlorophyll content in banana leaves. Paclobutrazol + diethyl aminoethyl hexanoate and chlormequat chloride can inhibit the biosynthesis of chlorophyll in banana seedlings.

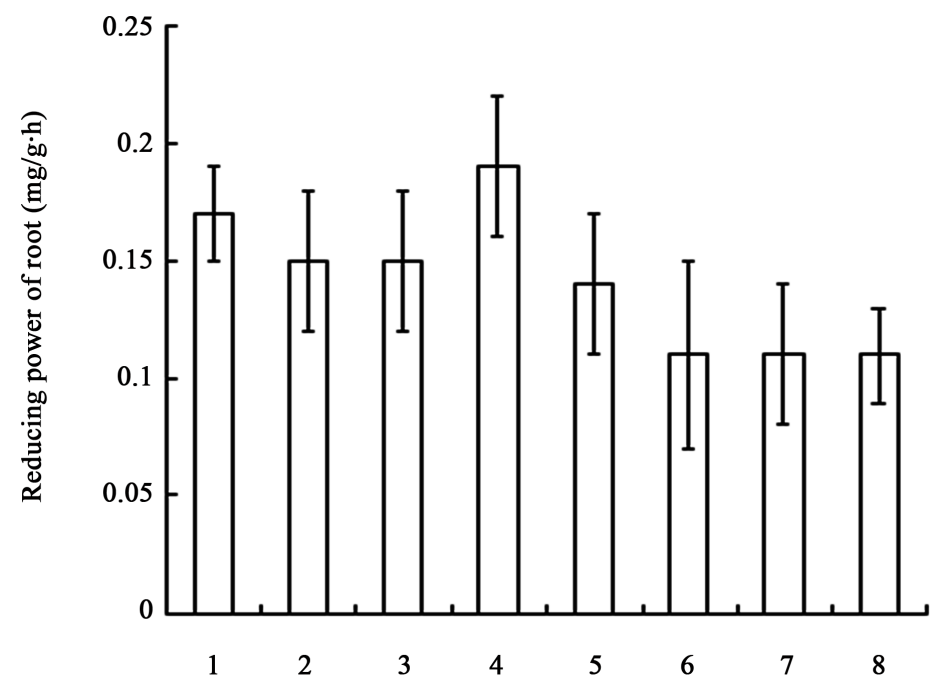

Figure 10. Reducing powers of roots of banana seedlings treated with different growth retardants. 1 - 8 represented paclobutrazol, diniconazole, paclobutrazol + brassins, paclobutrazol + diethyl aminoethyl hexanoate, diniconazole + brassins, diniconazole + diethyl aminoethyl hexanoate, chlormequat chloride, water, respectively.

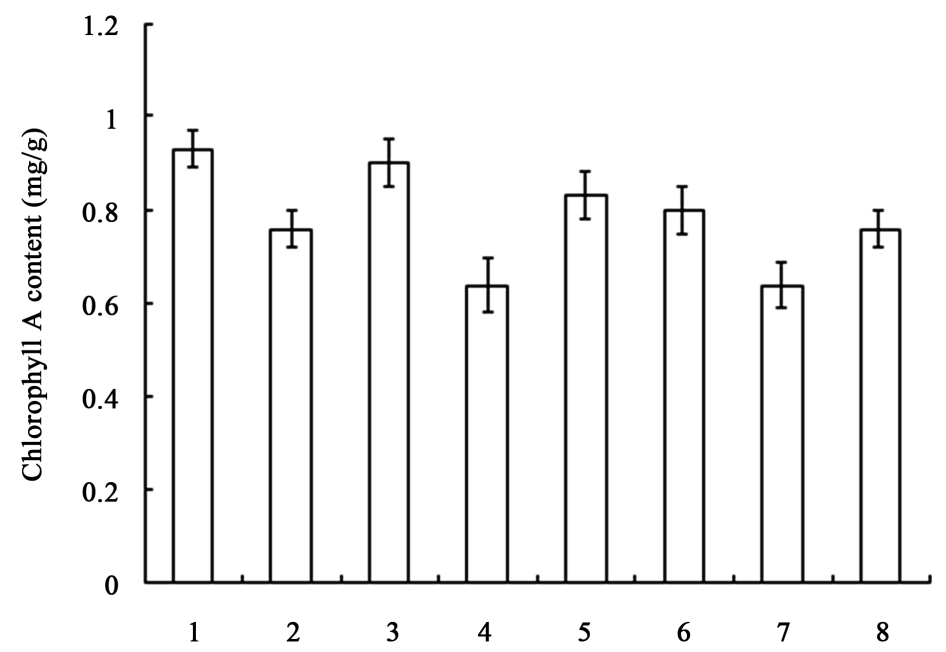

Figure 11. Chlorophyll A contents in leaves of banana seedlings treated with different growth retardants. 1 - 8 represented paclobutrazol, diniconazole, paclobutrazol + brassins, paclobutrazol + diethyl aminoethyl hexanoate, diniconazole + brassins, diniconazole + diethyl aminoethyl hexanoate, chlormequat chloride, water, respectively. 


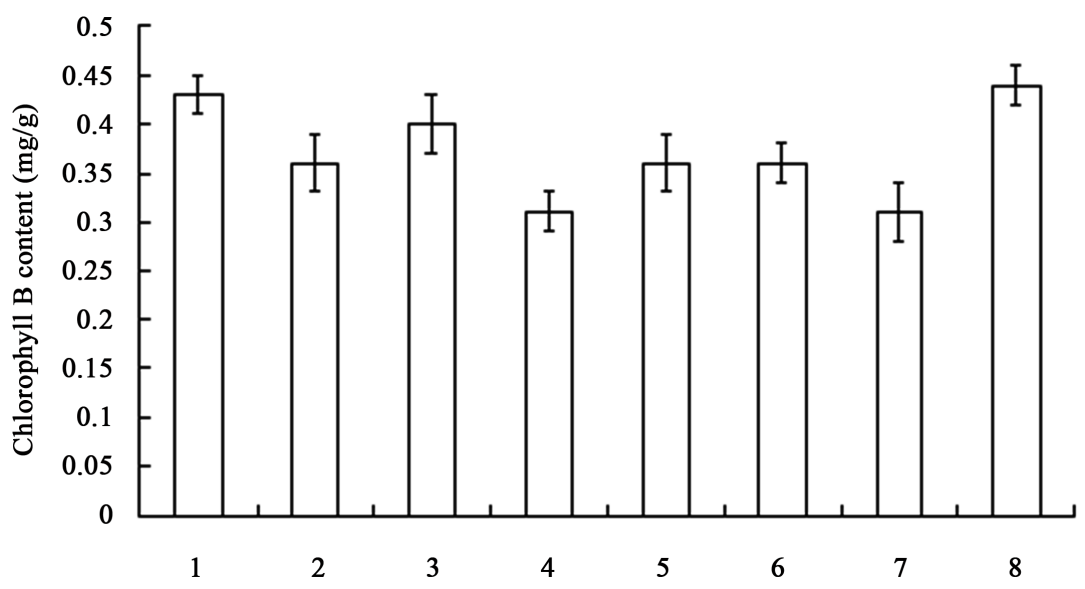

Figure 12. Chlorophyll B contents in leaves of banana seedlings treated with different growth retardants. 1 - 8 represented paclobutrazol, diniconazole, paclobutrazol + brassins, paclobutrazol + diethyl aminoethyl hexanoate, diniconazole + brassins, diniconazole + diethyl aminoethyl hexanoate, chlormequat chloride, water, respectively.

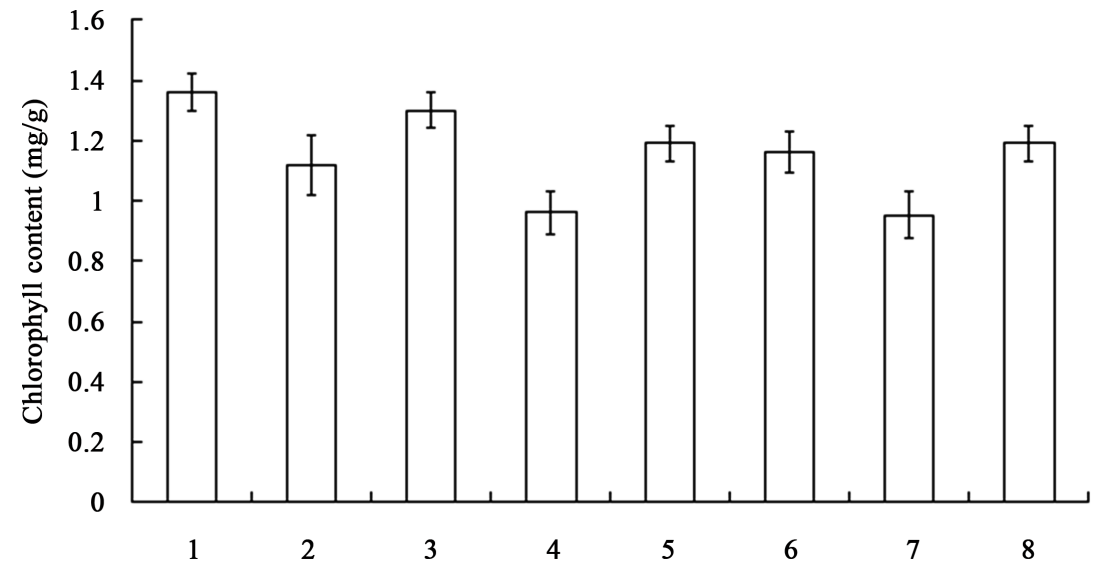

Figure 13. Total chlorophyll contents in leaves of banana seedlings treated with different growth retardants. 1 - 8 represented paclobutrazol, diniconazole, paclobutrazol + brassins, paclobutrazol + diethyl aminoethyl hexanoate, diniconazole + brassins, diniconazole + diethyl aminoethyl hexanoate, chlormequat chloride, water, respectively.

\section{Discussion}

Gibberellins are main phytohormones for controlling plant growth. Gibberellin can restore the dwarf mutants of pea and maize to normal height [9] [10]. If there were no gibberellins in plant, the stem will not be extent, the leaves will not be enlarged [11]. Several growth retardants or combinations were sprayed onto banana seedlings in this research. All of the heights of the seedlings sprayed with these retardants were significantly lower than that of control. The leaves of seedlings sprayed with retardants were shorter than that of seedlings sprayed with water. Pseudostem diameters of seedlings treated with retardants were less than that of control. The mechanism underlying these phenomena might be that after these chemicals entered banana seedlings, the biosynthesis of gibberellin was blocked and the growth of stem and leaf were inhibited. 
Gibberellins inhibit the growth of root [11]. However, after banana seedlings were sprayed with retardants for 30 days, all of the root length, root weight and root volume of the seedlings were significantly less than that of control. That the growth of root was inhibited by gibberellins might be concentration-dependent. The biosynthesis of gibberellins in plant included three steps: the biosynthesis of ent-kaurene, ent-kaurene was oxidized and GA12-aldehyde was formed, GA12-aldehyde was oxidized and different gibberellins were synthesized [12] [13]. These steps happened in proplastid, endoplasmic reticulum, and cytoplasm, respectively [13]. Chlormequat chloride inhibit the biosynthesis of gibberellins through inhibiting the enzyme CPP-synthase [14] [15]. GA1 in wheat seedlings and grains were lowered after the seedlings were sprayed with chlormequat chloride [16]. Gibberellins in sorghum seedlings were also reduced after the seedlings were treated with chlormequat chloride (Lee et al., 1998). After banana seedlings were sprayed with chlormequat chloride, the growth of seedlings was blocked. This might also be due to that GA1 in seedlings reduced.

Monooxygenases catalyze the steps that ent-kaurene is oxidized and ent-kaurenoic acid was synthesized. Paclobutrazol works through inhibiting monooxygenases [17] [18]. The levels of active gibberellins in plants decreased remarkably after being sprayed with paclobutrazol [19] [20]. After banana seedlings were treated with paclobutrazol for 30 days, the seedling height, seedling fresh weight, root length, root volume and chlorophyll content in leaves were all significantly lower than those corresponding values of seedlings sprayed with water only. This might be due to that after paclobutrazol entered banana seedlings and worked, the content of active gibberellins in seedlings decreased.

Root is a center of active metabolism. Hormones and amino acids were synthesized in root. Glucolysis, tricarboxylic acid cycle and nitrogen assimilation also happened in root. Reducing power of root can reflect the activity of root [21]. After being treated with retardants for 30 days, the reducing powers of seedlings sprayed with paclobutrazol and paclobutrazol + diethyl aminoethyl hexanoate were significantly higher than that of seedlings treated with water. These demonstrated that after paclobutrazol or paclobutrazol + diethyl aminoethyl hexanoate entered banana seedlings, metabolism activities in seedling roots was improved. Paclobutrazol and paclobutrazol + diethyl aminoethyl hexanoate can increase the metabolism activity in banana root.

\section{Conclusion}

Seven treatments (paclobutrazol, diniconazole, paclobutrazol + brassins, paclobutrazol + diethyl aminoethyl hexanoate, diniconazole + brassins, diniconazole + diethyl aminoethyl hexanoate, chlormequat chloride) were performed on banana seedlings and the growth was measured. In all of the treatments, the values of plant height, leaf length, pseudostem diameters, root length, root weight, root volume, fresh weight of above-ground tissues and fresh weight of seedlings were significantly less than those corresponding values of control. The reducing powers of roots of seedlings sprayed with paclobutrazol and paclobutrazol + diethyl 
aminoethyl hexanoate were remarkably higher than those of seedlings treated with water. Total chlorophyll content in leaves of seedlings sprayed with paclobutrazol was remarkably higher than that of seedlings treated with water. Total chlorophyll contents in leaves of seedlings treated with paclobutrazol + diethyl aminoethyl hexanoate and chlormequat chloride were lower than those of control. For delaying the growth of banana seedlings, chlormequat chloride was the best among the seven treatments. The mechanism might be that the enzyme CPP-synthase in seedlings was inhibited by chlormequat chloride.

\section{Acknowledgements}

This work was supported by the Key Research and Developmental Plan Item of Hainan Province (No. ZDYF2018072).

\section{Conflicts of Interest}

The authors declare no conflicts of interest regarding the publication of this paper.

\section{References}

[1] Shu, H., Sun, W., Wang, Z., Yin, M., Han, Q., Zhou, Z., Dai, M., Jin, Z., Li, J. and Chang, S. (2016) The Possible Analysis for Breeding Banana Varieties with High Resistance to Typhoon. Molecular Plant Breeding, 14, 1-11.

[2] Chang, S., Sun, W., Xu, G., Wei, Q., Li, J. and Shu, H. (2017) Enhancing Lodging Resistance of Banana Plant by Transforming 4-Coumarate: CoA Ligase Gene Mu4CL15. Molecular Plant Breeding, 15, 1-11.

[3] Sawan, Z.M. (2016) Cottonseed Yield and Its Quality as Affected by Mineral Nutrients and Plant Growth Retardants. Cogent Biology, 2, Article ID: 1245938. https://doi.org/10.1080/23312025.2016.1245938

[4] Ihara, Y. and Masuda, S. (2016) Cytosolic ppGpp Accumulation Induces Retarded Plant Growth and Development. Plant Signaling \& Behavior, 11, e1132966. https://doi.org/10.1080/15592324.2015.1132966

[5] Swetha, S., Padmalatha, T., Rao, K.D. and Shankar, A.S. (2014) Effect of Growth Retardants on Growth and Quality of Ornamental Foliage Plant Aglaonema. Progressive Horticulture, 46, 153-161.

[6] Liao, Y., Zeng, L., Li, P., Sun, T., Wang, C., Li, F., Chen, Y., Du, B. and Yang, Z. (2017) Influence of Plant Growth Retardants on Quality of Codonopsis Radix. Molecules, 22, 1655. https://doi.org/10.3390/molecules22101655

[7] Karimi, M., Ahmadi, A., Hashemi, J., Abbasi, A., Tavarini, S., Pompeiano, A., Guglielminetti, L. and Angelini, L.G. (2019) Plant Growth Retardants (PGRs) Affect Growth and Secondary Metabolite Biosynthesis in Stevia rebaudiana Bertoni under Drought Stress. South African Journal of Botany, 121, 394-401. https://doi.org/10.1016/j.sajb.2018.11.028

[8] Sarada, S., Simi, S. and Sudhadevi, P.K. (2017) Maintenance of Compact Growth form Suitable for Pot Culture in Foliage Plants Using Growth Retardants. Acta Horticulturae, 1165, 91-96. https://doi.org/10.17660/ActaHortic.2017.1165.14

[9] Brian, P.W. and Hemming, H.G. (1955) The Effect of Gibberellic Acid on Shoot Growth and Pea Seedlings. Physiologia Plantarum, 8, 669-681. 
https://doi.org/10.1111/j.1399-3054.1955.tb07760.x

[10] Phinney, B.O. (1956) Growth Response of Single-Gene Dwarf Mutants in Maize to Gibberellic Acid. Proceedings of the National Academy of Sciences of the United States of America, 42, 185-189. https://doi.org/10.1073/pnas.42.4.185

[11] Hedden, P. and Sponsel, V. (2015) A Century of Gibberellin Research. Journal of Plant Growth Regulation, 34, 740-760. https://doi.org/10.1007/s00344-015-9546-1

[12] Hedden, P. (1999) Recent Advances in Gibberellin Biosynthesis. Journal of Experimental Botany, 50, 553-563.

[13] Hedden, P. and Proebsting, W.M. (1999) Genetic Analysis of Gibberellin Biosynthesis. Plant Physiology, 119, 365-367. https://doi.org/10.1104/pp.119.2.365

[14] Weiwei, Z., Feng, X., Hua, C., Linling, L., Fuliang, C. and Shuiyuan, C. (2013) Effect of Chlorocholine Chloride on Chlorophyll, Photosynthesis, Soluble Sugar and Flavonoids of Ginkgo Biloba. Notulae Botanicae Horti Agrobotanici Cluj-Napoca, 41, 97-103. https://doi.org/10.15835/nbha4118294

[15] Sytar, O., Borankulova, A., Hemmerich, I., Rauh, C. and Smetanska, I. (2014) Effect of Chlorocholine Chlorid on Phenolic Acids Accumulation and Polyphenols Formation of Buckwheat Plants. Biological Research, 47, 19. https://doi.org/10.1186/0717-6287-47-19

[16] Mikofaj, W., Artur, S., Marta, S. and Roman, H. (2016) Effects of Chlorocholine Chloride (CCC) on Plant Height and Inulin Content in Jerusalem Artichoke ( $\mathrm{He}$ lianthus tuberosus L.). Bulletin of University of Agricultural Sciences and Veterinary Medicine Cluj-Napoca Horticulture, 73, 210-216. https://doi.org/10.15835/buasvmcn-hort:11957

[17] Carvalho-Zanão, M.P., Júnior, .L.A.Z., Grossi, J.A.S. and Pereira, N. (2018) Potted Rose Cultivars with Paclobutrazol Drench Applications. Ciência Rural, 48, e20161002. https://doi.org/10.1590/0103-8478cr20161002

[18] Sarker, B.C. and Rahim, M.A. (2018) Influence of Paclobutrazol on Growth, Yield and Quality of Mango. Bangladesh Journal of Agricultural Research, 43, 1-12. https://doi.org/10.3329/bjar.v43i1.36154

[19] Pokawattana, T., Gruneck, L., Seesangboon, A., Eungwanichayapant, P.D., Tovaranonte, J. and Popluechai, S. (2018) Effect of Paclobutrazol on Flower Development and Gene Expression of Jatropha. Chiang Mai Journal of Science, 45, 1323-1334.

[20] Tesfahun, W. (2018) A Review on: Response of Crops to Paclobutrazol Application. Cogent Food \& Agriculture, 4, Article ID: 1525169. https://doi.org/10.1080/23311932.2018.1525169

[21] Dong, Z., Shu, W., Zhang, B., Jin, S. and Ning, M. (2005) A Preliminary Study on the Reductive Activity of Cotton Lateral Root in Different Soil Layers. Acta Agronomica Sinica, 31, 219-223. 